\title{
PENGARUH TERAPI MUROTTAL AL-QUR'AN TERHADAP PENURUNAN INTENSITAS NYERI IBU BERSALIN KALA I FASE AKTIF DI RUANG BERSALIN RUMAH SAKIT UMUM DAERAH SOLOK SELATAN 2017
}

\author{
Faridah $\mathrm{BD}^{1}$, Yefrida ${ }^{2}$, Silvia Masmura ${ }^{3}$ \\ ${ }^{1}$ Politeknik Kesehatan Kemenkes Padang \\ email : faridahbd140@gmail.com \\ ${ }^{2}$ Politeknik Kesehatan Kemenkes Padang \\ email : evyrustam@gmail.com \\ ${ }^{3}$ Politeknik Kesehatan Kemenkes Padang \\ email : silviamasmuraa@gmail.com
}

\begin{abstract}
ABSTRAK
Persalinan adalah peristiwa bersejarah dalam siklus kehidupan seorang wanita. Biasanya ibu mengalami nyeri selama proses persalinan. Hal ini normal sepanjang itu bisa diterima dan ditoleransi ibu, bila tidak akan terjadi peningkatan hormon stres yang berakibat kepada ibu dan janin dan mengakibatkan proses persalinan terpaksa diakhiri dengan sectio. Angka persalinan sectio dari tahun ke tahun cendrung meningkat, menurut SDKI pada tahun 2007 sebesar 7\%, meningkat di 2012 menjadi 12\%, termasuk di RSUD Solok Selatan, diketahui tahun 2015 ada 194 orang, tahun 2016 menjadi 202 orang dan sampai Maret 2017 sudah 55 orang. Terapi Murottal Al-Qur'an dapat digunakan untuk mengurangi nyeri persalinan. Penelitian ini bertujuan untuk mengetahui pengaruh terapi Murottal Al-Qur'an terhadap penurunan intensitas nyeri persalinan kala I fase aktif. Metode penelitian yang digunakan adalah Pra Eksperimen One Group Pre and Postest Design. Sampel diambil secara Accidental Sampling pada ibu-ibu bersalin kala I fase aktif yang masuk kriteria inklusi yang berjumlah 13 orang. Pengambilan data dilakukan dengan menggunakan kuiseoner nyeri face pain rating scale. Analisa data dengan Shapiro Wilk test dan diuji dengan uji statistik Wilcoxon Signed Ranks test. Hasil penelitian yang dilaksanakan dari tanggal 28 Mei sampai dengan 13 Juni 2017, ditemukan rerata skala nyeri sebelum diberi terapi 8,307 dan rerata setelah diberi terapi 6,615, penurunan skala nyeri dari sebelum dengan sesudah pemberian terapi Murottal adalah 1,693. Dari uji statistik didapat $\mathrm{P}$ value $=0,001$ menunjukkan ada pengaruh pemberian terapi Murottal Al-Qur'an terhadap penurunan intensitas nyeri persalinan. Kesimpulan penelitian ini pemberian terapi Murottal Al-Qur'an terbukti mampu menurunkan nyeri persalinan kala I fase aktif. Diharapkan pemberian terapi Murottal Al-Qur'an menjadi alternatif intervensi dalam menurunkan nyeri persalinan kala I fase aktif.
\end{abstract}

Kata Kunci : "Nyeri Persalinan, Kala I Fase Aktif, Murottal Al-Qur’an"

\begin{abstract}
Labor is the historical event in the life cycle of a woman .Usually mother undergo pain during the delivery process. This is normal along it acceptable and tolerable mother, if not there will be an increase stress hormone that result to the mother and the fetus and resulted in the process of childbirth forced to ended with sectio. The delivery sectio from year to year increased, according SDKI in 2007 in amount of 7\% increase in 2012 become 12\%, including at Regional Hospital in Solok Selatan detected in 2015 the are 194 people, in 2016 become 202 people and until March 2017 people 55 al ready. The therapy murottal Al-Qur'an can be used to reduce pain during labor. Research aims to understand the influence of therapy murottal it Al-Qur'an to a decrease in intensital pain during labor when first stage active phase. The methodology used is a Pre Experiment one Group Pre and Postest Design. Samples taken as Accidental Sampling on mother maternity when first stage active phase in the criteria for inclusion for 13 peoples.The data was undertaken with both kuiseoner pain face pain ratings scale .An analysis of data by Shapiro Wilk test and tested by Wilcoxon Signed Ranks test. The researcher held from 28 May until 13 June in 2017, Results of the study found average pain scale before given therapy 8,307 and average through skills therapy 6,615. The pain of scale before in after the murottal therapy is 1,693 Of statistical tests obtained $P$ value $=0,001$ showing no influence the therapy Murottal Al-Qur'an. Conclusion this research the provision of therapy Murottal Al-Qur'an proven effective to reduce pain childbirth when i phase active.It is hoped through the therapy Murottal Al-Qur'an alternative intervention in lowering pain during labor when first stage active phase.
\end{abstract}

Keywords: “ Labor pain, first stage active phase, Murottal Al-Qur'an 


\section{PENDAhuluan}

Salah satu peristiwa yang bersejarah dalam siklus kehidupan seorang wanita adalah kehamilan, persalinan dan masa nifas. Kehamilan adalah pertumbuhan dan perkembangan janin intra uterin dimulai sejak konsepsi dan berakhir sampai permulaan persalinan. ${ }^{1}$ Sedangkan persalinan adalah suatu proses untuk mengeluarkan hasil konsepsi yaitu janin dan uri, dari jalan lahir atau jalan lain dimana janin dapat bertahan hidup di dunia luar, dimulai sejak uterus berkontraksi, yang menyebabkan serviks membuka, menipis, mendatar lalu mendorong janin keluar. $^{2}$

Biasanya ibu akan mengalami nyeri selama proses persalinan. Hal ini adalah kondisi yang normal, sepanjang hal itu bisa diterima dan ditoleransi ibu, nyeri terjadi akibat dari perubahan fisiologis selama persalinan. Nyeri adalah suatu keadaan yang tidak menyenangkan dan kompleks, merupakan fenomena yang sangat individual dengan komponen sensorik dan emosional. ${ }^{3}$ Rasa nyeri yang terjadi pada awal persalinan sampai dengan pembukaan lengkap lebih kurang 12-18 jam, dilanjutkan kala pengeluaran janin dan pengeluaran plasenta. Nyeri persalinan merupakan kombinasi nyeri fisik akibat kontraksi miometrium disertai regangan segmen bawah rahim, yang menyatu dengan kondisi psikologis ibu selama persalinan, yaitu kecemasan, kelelahan dan kekhawatiran sehingga dapat memperberat nyeri fisik yang sudah ada. $^{4}$

Nyeri kontraksi uterus mengakibatkan peningkatan aktifitas sistem syaraf simpatis sehingga terjadi perubahan- perubahan fisiologi tubuh, seperti kenaikan tekanan darah, kenaikan denyut jantung dan kenaikan laju pernafasan. Apabila tidak segera diatasi keadaan ini akan lebih meningkatkan rasa khawatir, tegang, takut dan stres yang sudah ada. ${ }^{5}$ Sehingga stres persalinan tidak hanya berakibat pada ibu, tetapi juga terhadap janin. Sebab pada ibu bersalin yang dalam keadaan stres akan terjadi pelepasan hormon stres antara lain kortisol, katekolamin, B-endorphin dan lain-lain. Kemudian terjadi vasokontriksi sistemik, termasuk kontriksi vasa utero plasenta, yang menyebabkan gangguan aliran darah ke janin, gangguan oksigen ke miometrium dan akhirnya kontraksi otot rahim melemah. ${ }^{6}$ Selanjutnya persalinan terpaksa diakhiri dengan persalinan tindakan seperti vakum, forcep dan sectio caesaria.

Dari tahun ke tahun angka melahirkan dengan sectio cendrung meningkat. Menurut data Survey Demografi dan Kesehatan Indonesia (SDKI) kecendrungan peningkatan SC di Indonesia, pada tahun 2007 sebesar 7\%, meningkat di tahun 2012 menjadi $12 \% .^{7}$ Begitu juga di Kabupaten Solok
Selatan, sebagai kabupaten yang baru berumur 13 tahun angka persalinan sectio di RSUD Solok Selatan setiap tahun juga meningkat. Dari survey awal yang dilakukan disana, diketahui pada tahun 2015 ada 194 orang persalinan sectio, di tahun 2016 ada 202 orang dan sampai Maret 2017 sudah ada 55 orang ibu bersalin yang di tindak dengan sectio. Menurut keterangan kepala ruangan kamar bersalin, tindakan sectio sebagian besar dilakukan karena ada komplikasi dari nyeri persalinan yaitu fetal distres. Dari wawancara dengan 10 pasien post sectio mereka mengatakan rata-rata mengalami nyeri, khawatir dan takut saat persalinan terutama pembukaan hampir lengkap atau kala I fase aktif.

Banyak metode yang dilakukan untuk menurunkan nyeri pada persalinan, baik secara farmakologi maupun non farmakologi. Penggunaan metode farmakologi mempunyai efektifitas yang lebih baik, dibanding dengan metode non farmakologi. Namun penggunaan metode farmakologi sering menimbulkan efek samping dan kadang tidak memiliki efek yang diharapkan. ${ }^{8}$ Metode farmakologi adalah metode penghilang nyeri dengan menggunakan obat-obatan, seperti analgetik dan anastesi. Sedangkan metode non famakologi adalah metode tanpa obat-obatan, selain menurunkan nyeri pada persalinan juga mempunyai efek non invasif, sederhana, efektif dan tanpa efek yang membahayakan. ${ }^{9}$

Alternatif terapi non farmakologi yang dipakai diantaranya adalah relaksasi, massage, kompres dan distraksi. Salah satu metode non farmakologi adalah distraksi. Distraksi yaitu mengalihkan perhatian pada hal lain, sehingga pasien akan lupa terhadap nyeri yang dialami. ${ }^{10}$ Terbagi atas distraksi visual, distraksi pendengaran, distraksi pernafasan dan distraksi intelektual. Salah satu metode distraksi pendengaran yang efektif adalah terapi murottal. Murottal adalah rekaman suara bacaan Al-Qur'an yang dilagukan oleh seseorang qori. ${ }^{11}$ Metode distraksi menggunakan murottal Al-Qur'an lebih efektif dari pada metode distraksi yang lain, karena merupakan pendekatan terapi non farmakologi secara keagamaan, tentu lebih cepat diterima oleh pasien, yang dominan beragama Islam.

Terapi murottal Al-Qur'an dengan keteraturan bacaannya yang benar juga merupakan sebuah musik Al-Qur'an yang mampu mendatangkan ketenangan bagi orang yang mendengarnya. ${ }^{12}$ Penelitian yang dilakukan Wahidin, S dkk, 2014 mengatakan pemberian murottal Al-Qur'an terbukti efektif meningkatkan kadar B-Endorphin pada ibu bersalin kala I fase aktif. Penelitian Siti Chunaeni dkk, 2016 juga menemukan perbedaan hasil yang signifikan intensitas nyeri persalinan, sebelum dan sesudah diberi terapi murottal Al-Qur'an pada ibu bersalin kala I fase aktif. 
Kepala ruangan kamar bersalin RSUD Solok Selatan mengatakan belum ada penelitian tentang penanganan nyeri persalinan, serta ibu-ibu bersalin kala I disana sering mengeluh tentang nyeri persalinan yang mereka hadapi, sehingga berakibat ke peningkatan tekanan darah, peningkatan nadi dan pernafasan. Bahkan akhirnya terpaksa dilakukan tindakan sectio karena adanya komplikasi yang ditimbulkan oleh nyeri persalinan tersebut. Berdasarkan latar belakang tersebut peneliti tertarik untuk mengetahui

“Pengaruh Terapi Murottal Al-Qur'an Terhadap Penurunan Intensitas Nyeri Ibu Bersalin Kala I Fase Aktif Di Ruang Bersalin RSUD Solok Selatan Tahun 2017'.

\section{METODE PENELITIAN}

Jenis penelitian ini adalah pra eksperiment one group pre and posttest design. Telah dilaksanakan di ruang bersalin RSUD Solok Selatan, pada tanggal 28 Mei sampai dengan 13 Juni 2017. Populasi dalam penelitian ini ibu-ibu bersalin kala I fase aktif yang datang dan melahirkan di ruang bersalin RSUD Solok Selatan pada tanggal 28 Mei sampai dengan 13 Juni 2017 tersebut. Pengambilan sampel menggunakan teknik pengambilan sampel non probability sampling secara accidental sampling. Didapatkan responden sebanyak 13 orang, dengan karakteristik responden usia 21 sampai dengan 45 tahun, dengan 6 orang primipara dan 7 orang multipara, semuanya masuk kriteria inklusi. Pengambilan data tentang nyeri persalinan menggunakan kuesioner face pain rating scale. Analisa data penelitian dilakukan dengan sistem komputerisasi dengan Shapiro Wilk test didapat distribusi data tidak normal, dilanjutkan dengan uji statistik non parametrik Wilcoxon Signed Ranks test.

\section{HASIL PENELITIAN}

\section{A.Hasil Penelitian}

\section{Analisis Univariat}

\section{a. Intensitas Skala Nyeri Ibu Bersalin Kala I Fase Aktif Sebelum Diberi Terapi Murottal Al-Qur'an}

Tabel berikut memperlihatkan rerata intensitas skala nyeri sebelum diberi terapi Murottal Al-Qur'an.
Tabel 1 Rerata Intensitas Skala Nyeri Sebelum Diberi Terapi Murottal Al-Qur'an pada Ibu Bersalin Kala I Fase Aktif Di Ruang Bersalin RSUD Solok Selatan Tahun 2017

Intensitas Nyeri

\begin{tabular}{ccccc} 
Ibu Bersalin & Mean & SD & Min-Max & n \\
\hline Pretest & 8,307 & 1,601 & $6-10$ & 13
\end{tabular}

Berdasarkan tabel 1 dapat dilihat dari 13 orang responden ibu bersalin kala I fase aktif, didapatkan rata-rata skala nyeri ibu sebelum diberi terapi murottal Al-Qur'an adalah 8,307 dengan standar deviasi adalah 1,601. Nilai intensitas skala nyeri persalinan kala I fase aktif terendah adalah 6 dan tertinggi adalah 10 .

b.Intensitas Skala Nyeri Ibu Bersalin Kala I Fase Aktif Setelah Diberi Terapi Murottal Al-Qur'an

Tabel berikut memperlihatkan rerata intensitas skala nyeri setelah diberi terapi Murottal Al-Qur'an.

Tabel 2 Rerata Intensitas Skala Nyeri Setelah Diberi Terapi Murottal Al-Qur'an pada Ibu Bersalin Kala I Fase Aktif Di Ruang BersalinRSUD Solok Selatan Tahun 2017

\begin{tabular}{ccccc}
\hline Intensitas Nyeri & & & & \\
& Mean & SD & Min-Max & n \\
\cline { 2 - 5 } $\begin{array}{c}\text { Ibu Bersalin } \\
\text { Postest }\end{array}$ & 6,615 & 1,709 & $4-8$ & 13 \\
\hline
\end{tabular}

Berdasarkan tabel 2, dapat dilihat dari 13 orang ibu bersalin kala I fase aktif didapatkan rata-rata skala nyeri ibu setelah diberi terapi murottal Al-Qur'an adalah 6,615 dengan standar deviasi adalah 1,709. Nilai intensitas skala nyeri persalinan kala I fase aktif terendah adalah 4 dan tertinggi adalah 8 .

\section{Analisis Bivariat}

Pengaruh Terapi Murottal Al-Qur'an Terhadap Intensitas Skala Nyeri Ibu Bersalin Kala I Fase Aktif di Ruang Bersalin RSUD Solok Selatan Tahun 2017

Tabel berikut memperlihatkan hasil pengolahan uji statistik non parametrik Wilcoxon Signed Ranks test, untuk melihat pengaruh terapi Murottal Al-Qur'an terhadap intensitas skala nyeri ibu bersalin kala I fase aktif. 
Tabel 3 Pengaruh Terapi Murottal Al-Qur'an Terhadap Intensitas Skala Nyeri Ibu Bersalin Kala I Fase Aktif di Ruang Bersalin RSUD Solok Selatan Tahun 2017

\begin{tabular}{|c|c|c|c|c|c|c|c|}
\hline \multirow{3}{*}{ T-Test } & \multicolumn{6}{|c|}{$95 \%$ confidence } & \multirow{2}{*}{ p } \\
\hline & Mean & $\begin{array}{c}\text { Deviatio } \\
\text { n }\end{array}$ & \multicolumn{2}{|c|}{ Difference } & $\mathbf{t}$ & df & \\
\hline & & & Lower & Upper & & & value \\
\hline Pretest dan & & & & & 8,12 & & \\
\hline Postest & 1,693 & 0,751 & 1,238 & 2,146 & 4 & 12 & 0,001 \\
\hline
\end{tabular}

Berdasarkan tabel 3, didapatkan rata-rata penurunan skala nyeri ibu bersalin kala I fase aktif sebelum dengan sesudah diberikan terapi Murottal Al-Qur'an adalah 1,693 dan standar deviasi 0,751. Hasil uji statistik non parametrik Wilcoxon Signed Ranks test didapatkan nilai $p$ value $=0,001$ kecil dari $\alpha(0,05)$, maka dapat disimpulkan adanya pengaruh pemberian terapi Murottal Al-Qur'an terhadap penurunan intensitas skala nyeri ibu bersalin kala I fase aktif di ruang bersalin RSUD Solok Selatan tahun 2017.

\section{IV.PEMBAHASAN}

\section{Analisis Univariat}

a.Intensitas Skala Nyeri Ibu Bersalin Kala I Fase Aktif Sebelum Diberi Terapi Murottal Al-Qur'an di Ruang Bersalin RSUD Solok Selatan Tahun 2017

Berdasarkan hasil penelitian, didapatkan bahwa ratarata skala nyeri ibu bersalin kala I fase aktif sebelum diberi terapi Murottal Al-Qur'an adalah 8,307 dengan standar deviasi adalah 1,601. Nilai intensitas skala nyeri terendah adalah 6 dan tertinggi adalah 10 . Menurut skala nyeri numeric rating scale berarti skala nyeri ibu bersalin kala I fase aktif yang menjadi responden peneliti saat itu berada di tingkat nyeri sedang sampai dengan hebat. Menurut skala nyeri face pain rating scale responden peneliti berada pada wajah cemberut sampai dengan menangis kesakitan.

Sejalan dengan penelitian Siti Chunaeni, Lusiana dan Esti Handayani di BPM Puskesmas Mungkid Magelang (2016) yang juga menemukan rata - rata skala nyeri sebelum diberi terapi Murottal di skala nyeri sedang sampai dengan berat. Menurut asumsi peneliti ini terjadi karena kesamaan kriteria responden, yaitu responden yang berada di kala I fase aktif persalinan. Dalam proses persalinan kala I fase aktif merupakan suatu fase dimana terjadi kontraksi uterus yang makin lama makin kuat, seiring dengan pembukaan yang makin besar dan penurunan janin yang makin mendekati pintu rahim. Perubahan fisiologi tersebut menjadikan rasa nyeri yang juga semakin meningkat dirasakan responden.
Nyeri adalah suatu keadaan yang tidak menyenangkan dan kompleks, merupakan fenomena yang sangat individual dengan komponen sensorik dan emosional seseorang. ${ }^{3}$ Menurut asumsi peneliti, karena rasa nyeri adalah fenomena yang sangat individual dengan komponen sensorik dan emosional seseorang, hal itulah yang menyebabkan persepsi nyeri ibu-ibu bersalin kala I fase aktif juga berbeda. Dimana karakteristik responden peneliti adalah dari usia 21 sampai dengan 45 tahun, sehingga persepsi nyeri antara ibu yang usia muda, tentu berbeda dengan ibu yang lebih tua, begitu juga perbedaan karakteristik jumlah anak, dimana nyeri antara ibu primipara tentu berbeda dengan nyeri ibu multipara. Ini terjadi karena pada ibu multipara ada kesiapan mental yang lebih dibandingkan ibu primipara dalam menghadapi proses persalinan.

Nyeri persalinan yang dirasakan merupakan kombinasi dari nyeri fisik akibat kontraksi miometrium disertai regangan segmen bawah rahim, yang menyatu dengan kondisi psikologis ibu selama persalinan, yaitu kecemasan, kelelahan dan kekhawatiran sehingga dapat memperberat nyeri fisik yang sudah ada. ${ }^{4}$ Dimana kondisi psikologis antara ibu yang satu dengan ibu yang lain yang berbeda, sudah tentu juga mempengaruhi persepsi rasa nyeri yang dirasakan. Kemudian karena responden yang menjadi subjek penelitian adalah dengan rentang pembukaan 4-8, menjadikan perbedaan skala nyeri masing-masing responden, semakin besar pembukaan maka semakin tinggi intensitas nyeri yang dirasakan

responden, diakibatkan kontraksi miometrium dan regangan segmen bawah rahim yang semakin kuat juga, begitu juga sebaliknya semakin kecil pembukaan maka nyeri yang dirasakan juga lebih kecil, karena kontraksi rahim yang masih jarang dan regangan segmen bawah rahim yang juga masih kecil.

b.Intensitas Skala Nyeri Ibu Bersalin Kala I Fase Aktif Setelah Diberi Terapi Murottal Al-Qur'an di Ruang Bersalin RSUD Solok Selatan Tahun 2017

Berdasarkan hasil penelitian, didapatkan bahwa rata-rata skala nyeri ibu bersalin kala I fase aktif setelah diberi terapi Murottal Al-Qur'an adalah 6,615 dengan standar deviasi adalah 1,709. Nilai intensitas skala nyeri persalinan kala I fase aktif terendah 4 dan tertinggi 8 . Menurut skala nyeri face pain rating scale ibu bersalin kala I fase aktif yang telah diberi terapi Murottal berada pada wajah sedikit cemberut sampai dengan wajah sangat meringis dan menurut numeric rating scale berada pada skala nyeri sedang sampai dengan nyeri berat. Sejalan dengan penelitian Rohmi Handayani dkk (2014) di RSUD 
Prof DR Margono, yang juga menemukan penurunan skala nyeri setelah diberi terapi Murottal Al-Qur'an. Dari data responden yang peneliti dapatkan tersebut dapat dilihat penurunan sebagian besar skala nyeri ibu-ibu bersalin setelah diberi terapi Murottal Alqur'an. Dimana sebelum diberi terapi skala nyeri tertinggi adalah 10 dan yang terendah adalah 6 , setelah diberi terapi Murottal skala nyeri tertinggi adalah 8 yang terendah adalah 4 .

Banyak metode yang dapat dilakukan untuk menurunkan nyeri persalinan, baik secara farmakologi maupun non farmakologi. Terapi non farmakologi lebih mudah digunakan, karena sederhana dan tanpa efek yang membahayakan, termasuk salah satunya terapi Murottal Al-Qur'an. Terapi Murottal

Al-Qur'an adalah terapi yang memperdengarkan alunan bacaan Al-Qur'an kepada pasien, untuk membantu pasien mengalihkan pikirannya dari rasa nyeri yang sedang dirasakannya.

Terapi Murottal Al-Qur'an dengan keteraturan bacaannya yang benar juga merupakan sebuah musik Al-Qur'an yang mampu mendatangkan ketenangan bagi orang yang mendengarnya. ${ }^{11}$ Menurut asumsi peneliti, kondisi seorang ibu yang dalam proses persalinan adalah sebuah kondisi yang sangat membutuhkan banyak suport dan sugesti, termasuk realitas kesadaran terhadap adanya Tuhan Yang Maha Esa. Terapi Murottal Al-Qur'an membantu ibu bersalin mengalihkan rasa nyeri dan meningkatkan totalitas kepasrahan kepada Allah SWT. Keadaan ini menyebabkan otak berada pada gelombang alpha, merupakan keadaan energi otak pada frekuensi 7-14 $\mathrm{hz}$, disini otak berespon menyingkirkan stres dan kecemasan. ${ }^{22}$ Sehingga ibu bersalin yang menjadi responden peneliti terlihat lebih rileks dan tenang dalam menghadapi nyeri persalinan yang dirasakanya dan saat dilakukan pengukuran skala nyeri sebagian besar mengatakan nyeri berkurang.

\section{Analisis Bivariat}

Pengaruh Terapi Murottal Al-Qur'an Terhadap Penurunan Intensitas Nyeri Ibu Bersalin Kala I Fase Aktif di Ruang Bersalin RSUD Solok Selatan tahun 2017

Berdasarkan hasil penelitian dan uji statistik, didapatkan rata-rata penurunan skala nyeri ibu bersalin kala I fase aktif sebelum dengan sesudah diberikan terapi Murottal Al-Qur'an adalah 1,693 dan standar deviasi 0,751. Hasil uji statistik Wilcoxon Signed Ranks test didapatkan nilai $p$ value $=0,001$ kecil dari $\alpha(0,05)$, maka dapat disimpulkan adanya pengaruh pemberian terapi Murottal Al-Qur'an terhadap penurunan intensitas skala nyeri ibu bersalin kala I fase aktif di ruang bersalin RSUD Solok Selatan tahun 2017.

Hasil penelitian ini sejalan dengan penelitian Siti Chunaeni, Lusiana dan Handayani (2016) di BPM wilayah kerja

puskesmas Mungkid Kabupaten Magelang, yang mengatakan perbedaan intensitas nyeri persalinan sebelum dengan sesudah diberi terapi Murottal AlQur'an pada ibu bersalin kala I fase aktif. Juga sejalan dengan penelitian Wahida S, Nuryanto dan Andarini (2014) di RS Abunawas Kendari, yang menemukan peningkatan kadar B-Endorphin pada ibu-ibu bersalin kala I fase aktif yang telah diberi terapi Murottal Al-Qur'an.

Teori tentang nyeri yang diajukan oleh Melzak da Wall (1965) ${ }^{7}$ mengatakan bahwa keberadaan dan intensitas nyeri tergantung pada transmisi tertentu pada impuls syaraf, mekanisme gate/pintu sepanjang sistem syaraf mengontrol dan mengendalikan transmisi nyeri, jika pintu terbuka impuls nyeri dirasakan, dan sebaliknya jika pintu tertutup impuls nyeri tidak dirasakan. Pemberian terapi Murottal AL-Qur'an pada ibu-ibu bersalin kala I

fase aktif yang menjadi responden peneliti, menjadikan gate/pintu sistem syaraf transmisi nyeri tertutup. Karena responden teralihkan perhatiannya dari rasa nyeri yang sedang dirasakannya, sehingga sebagian besar mengatakan rasa nyeri menjadi agak berkurang.

Menurut pendapat peneliti bacaan Al-Quran yang dilantunkan dengan penuh

penghayatan, didengarkan dengan kepasrahan, membawa responden yang ibu-ibu bersalin kala I fase aktif, kepada suatu kesadaran akan keagungan dan kebesaran Allah SWT, sehingga timbul suatu totalitas kesadaran penyerahan diri kepada kekuasaan Allah SWT, yang akhirnya membuat responden lebih tenang dan rileks serta religius dalam menghadapi nyeri dan proses persalinan tersebut.

Kondisi responden yang dalam keadaan cemas, khawatir dan takut dalam menghadapi persalinan, membuat mereka menginkan suasana yang lebih tenang dan rileks, dengan memberi terapi Murottal Al-Qur'an membantu menciptakan suasana tersebut, karena suami dan keluarga yang mendampingi ikut khidmat dan tenang, karena mereka menyadari lantunan ayat suci yang sedang di dengar responden memang butuh suasana khidmat dan tenang. Kemudian diantara responden ada yang tidak berpengaruh pemberian terapi Murottal AlQur'an terhadap intensitas nyerinya, menurut asumsi 
peneliti ini mungkin terjadi karena responden kurang rileks dan tenang, sehingga pengalihan pikirannya dari rasa nyeri yang dirasakan tidak terjadi, maka pintu gerbang nyeri tidak atau kurang tertutup, sehingga intensitas nyeri tetap sama antara sebelum dan sesudah diberi terapi Murottal Al-Qur'an.

Intensitas nyeri setelah diberi terapi mengalami penurunan rata-rata 1,692 dengan standart deviasi 0,751 , menurut asumsi peneliti ini terjadi karena pemberian terapi dengan mempergunakan sistem pendengaran memiliki kendala kondisi peralatan yang mempergunakan headset, yang bisa sewaktuwaktu longgar, karena responden yang gelisah menahan nyeri kontraksi rahim. Mungkin bila pemberian terapi digabung atau dipasangkan dengan metode non farmakologi lain seperti pijat dan kompres, bisa diperoleh hasil yang lebih baik.

\section{KESIMPULAN DAN SARAN A.Kesimpulan}

Berdasarkan hasil penelitian yang telah didapatkan tentang pengaruh terapi Murottal Al-Qur'an terhadap penurunan intensitas nyeri ibu bersalin kala I fase aktif di ruang bersalin RSUD Solok Selatan tahun 2017 dapat ditarik kesimpulan sebagai berikut :

1. Rerata intensitas skala nyeri ibu bersalin kala I fase aktif sebelum diberi terapi Murottal AlQur'an adalah 8,307

2. Rerata intensitas skala nyeri ibu bersalin kala I fase aktif setelah diberi terapi Murottal AlQur'an adalah 6,615

3. Terdapat perbedaan skala nyeri sebelum dengan setelah diberi terapi Murottal Al- Qur'an.

\section{B.Saran}

Berdasarkan kesimpulan yang

didapatkan dari hasil penelitian maka peneliti menyarankan :

\section{Bagi Rumah Sakit}

Harapan peneliti pemberian terapi Murottal AlQur'an dapat dijadikan salah satu intervensi pelayanan pasien inpartu yang beragama Islam di ruang bersalin RSUD Solok Selatan, karena ini merupakan salah satu cara mengurangi nyeri yang aman dan paling mudah diterapkan, disamping intervensi non medis lain.

2. Bagi Institusi Pendidikan Harapan

Peneliti agar hasil penelitian ini dapat dijadikan bahan pertimbangan dalam peningkatan kualitas mutu pendidikan kebidanan Poltekkes Kemenkes Padang khususnya Asuhan Persalinan Normal pada ibu bersalin.
3. Bagi Peneliti selanjutnya

Harapan peneliti agar penelitian ini dapat dijadikan sebagai pembanding untuk penelitian lebih lanjut dalam menerapkan metode penghilang nyeri yang lain seperti hipnobirthing, massage, kompres dan lain-lain.

\section{DAFTAR PUSTAKA}

1. Manuaba IBG, Manuaba IA Chandranita, Manuaba IBG Fajar. Buku Ajar Patologi Obstetri Untuk

Mahasiswa Kebidanan, Penerbit Buku

Kedokteran Jakarta. EGC. 2009

2. Muchtar Rustam, Sinopsis Obstetri Jilid I. Jakarta. EGC.2006 Indrayani, Moudi. Up date Asuhan Persalinan dan Bayi Baru Lahir. CV Trans Info Media, Jakarta. I. 2016

4. Westheiner G. Mengkreasi Kehamilan dan Menjaga Kasih Sayang. Raja Grafindo Persada. Jakarta. 2000

5. Bobak. Keperawatan Maternitas. Edisi 4. Cetakan I. EGC. 2005

6. Yanti, Buku Ajar Asuhan Kebidanan Persalinan. Pustaka Rihana. Yogyakarta. 2009

7. Kementerian Kesehatan RI. Survey Demografi dan Kesehatan Indonesia 2012. [sumber online] 2013. Tersedia dari: http://www.depkes.go.id

8. Maryunani, Nyeri Dalam Persalinan Teknik dan Cara penanganannya. Trans Info Media, Jakarta. 2010

9. Tournaire M, Theau Yonneau A. Complementary and alternative approaches to pain relief during labor. Evid Based Complement Alternat Med. 2007

10. Potter, Patricia A dan Perry, Anne Griffin, Buku Ajar Fundamental Keperawatan. Vol 2. EGC. Jakarta.2005

11. Saadulloh, Sembilan Cara Tepat Menghafal Al-Qur'an. Gumalasari. Jakarta 2006

12. Ghofar A and Ningsih L The Influence of Therapy and Music Therapy : Listening AlQur'an Juz Amma to Anxiety Responden at Todler. Prosiding Seminar Competitive Advantage Unipdu. Jombang

13. Manuaba, I.B.G. Ilmu Kebidanan, Penyakit Kandungan dan Keluarga Berencana Untuk Pendidikan Bidan. EGC. Jakarta. 2001

14. Prawiroharjo, S. Ilmu Kebidanan. Bina Pustaka. Jakarta. 2002

15. Aprillia Y. Hipnostetri : Rileks Nyaman dan Aman Saat Hamil dan Melahirkan. Jakarta. Gagas Media. 2010

16. Pillitteri. Maternal and Child Health Nursing. 2003

17. Remolda, P. 2009. Pengaruh Al-Qur'an pada Manusia Dalam Perspektif Fisiologi dan Psikologi.http://www.theedc.com 
18. Saryono, Anggraeni, Metodologi Penelitian Kualitatif dan Kuantitatif Dalam Bidang Kesehatan. Nuha Medika.Yogyakarta.I. 2013

19. Siswanto, Susila, Suyanto. Metodologi Penelitian Kesehatan Dan Kedokteran. Bursa Ilmu. Yogyakarta.I. 2015

20. Sugiono. Metode Penelitian Kuantitatif Kualitatif \& RND. Bandung. Alfabeta. 2010
21. Notoatmojo,S. Metodologi Penelitian Kesehatan. Edisi Revisi. Jakarta. Rieneka Cipta. 2010

22. MacGregor, S, Piece of Mind Menggunakan Kekuatan Pikiran Bawah Sadar Untuk Mencapai Tujuan. Jakarta. 2001 